Sierpińska Lidia, Kopeć Justyna. Conditioning of nurses' work in infectious diseases wards in association with the COVID-19 pandemic. Journal of Education, Health and Sport. 2021;11(12):350-358. eISSN 2391-8306. DOI http://dx.doi.org/10.12775/JEHS.2021.11.12.029

https://apcz.umk.pl/JEHS/article/view/JEHS.2021.11.12.029

https://zenodo.org/record/5812882

The journal has had 40 points in Ministry of Education and Science of Poland parametric evaluation. Annex to the announcement of the Minister of Education and Science of December 1, 2021. No. 32343. Has a Journal's Unique Identifier: 201159. Scientific disciplines assigned: Physical Culture Sciences (Field of Medical sciences and health sciences); Health Sciences (Field of Medical Sciences and Health Sciences).

Punkty Ministerialne z 2019 - aktualny rok 40 punktów. Zalącznik do komunikatu Ministra Edukacji i Nauki z dnia 1 grudnia 2021 r. Lp. 32343. Posiada Unikatowy Identyfikator Czasopisma: 201159. Przypisane dyscypliny naukowe:Nauki o kulturze fizycznej (Dziedzina nauk medycznych i nauk o zdrowiu); Nauki o zdrowiu (Dziedzina nauk medycznych i nauk o zdrowiu).

(c) The Authors 2021;

This article is published with open access at Licensee Open Journal Systems of Nicolaus Copernicus University in Torun, Polan

Open Access. This article is distributed under the terms of the Creative Commons Attribution Noncommercial License which permits any noncommercial use, distribution, and reproduction in any medium,

provided the original author (s) and source are credited. This is an open access article licensed under the terms of the Creative Commons Attribution Non commercial license Share alike.

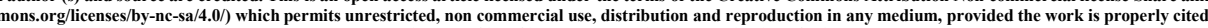
The authors declare that there is no conflict of interests regarding the publication of this paper.

Received: 05.12.2021. Revised: 23.12.2021. Accepted: 31.12.2021.

\title{
Conditioning of nurses' work in infectious diseases wards in association with the COVID-19 pandemic
}

\author{
Lidia Sierpińska ${ }^{1}$, Justyna Kopeć ${ }^{2}$ \\ ${ }^{1}$ Military Clinical Hospital No. 1 with Polyclinic, Independent Public Health Unit, Lublin \\ ${ }^{2}$ Students' Scientific Circle, University of Economics and Innovation, Lublin
}

\section{Abstract \\ Introduction}

Infectious diseases, due to their specificity and rapid spread, require a special, individual approach, not only to the treatment, but also to the protection of medical staff against infection.

Objective: The aim of the study is recognition of the conditioning of work of nurses in hospitals dedicated to COVID-19, at the time of pandemic.

\section{Materials and Method}

The study included 100 nursing staff - 78 females (78\%) and 22 males (22\%) employed in Polish hospitals dedicated to care of patients with COVID-19 by virtue of the Minister of Health [5]. The research material was collected during the period from 15 January 2021 - do 12 February 2021 . The largest group in the study was aged under $30(32 \%)$, and similarly those aged $31-40(31 \%)$. The respondents aged $41-50$ constituted $21 \%$ of the nursing staff examined. The smallest group of nurses was aged over $60(16 \%)$. The largest number of the nursing staff lived in urban areas (78\%), whereas the reminder in rural areas $(22 \%)$.

The study was conducted by the method of a diagnostic survey, using a questionnaire technique, while the research tool was an author-constructed questionnaire designed for the purpose of the presented study. The questionnaires were sent to hospitals dedicated to COVID-19 in various localities in Poland, with a request for obtaining consent from decision-makers in these facilities. Considering the pandemic, in none of these facilities a consent was expressed to send the documents by post in a paper form. Therefore, the documents were sent by e-mail, and received also in this form. The questionnaire was also posted on a website and the link was provided on the Internet nursing forums.

\section{Conclusions}

1. In dedicated hospitals it is necessary to optimize the equipment in the ward indispensable for care of patients with COVID-19, which would improve the working conditions of nurses.

2. It is advisable to adjust the employment of nurses to the demand for nursing care of patients seriously ill with COVID-19, treated in dedicated hospitals. 
3. In infectious diseases hospitals, in-hospital training courses should be intensified concerning the OSH and sanitary-hygienic principles in care of patients with COVID-19, because $1 / 4$ of the examined nurses indicated such a need.

4. In dedicated hospitals the nursing staff should be provided with more personal protection equipment, and trainings should be intensified concerning the principles of using the above-mentioned means while taking care of patients with COVID-19.

5. Nurses in dedicated hospitals experienced chronic stress due to the great psychological load during care of patients with COVID-19, which indirectly exerted a negative effect on the effectiveness of their work.

\section{Key words: nurses' work; infectious diseases; COVID-19; pandemic}

\section{Introduction}

Infectious diseases, due to their specificity and rapid spread, require a special, individual approach, not only to the treatment, but also to the protection of medical staff against infection.

At the time of the COVID-19 pandemic many hospitals in Poland were temporarily transformed into hospitals dedicated to coronavirus disease. In the situation of a sudden increase in morbidity additional hospitals for infectious diseases enable the provision of medical care for infected patients who need urgent hospitalization.

The admission of a patient with COVID-19 to an infectious diseases ward requires the implementation of procedures, which would provide safety for the medical staff. Each admitted patient is approached as a potential carrier of SARS-CoV-2 virus. At the time of the pandemic, nurses employed in hospitals dedicated to coronavirus disease, through direct contact with a patient with COVID-19 are exposed to the risk of infection with SARS-CoV-2 virus. While providing care for this group of patients they encounter various problems and barriers [1,2]. These may be: lack of equipment and personal protection means, nurse staffing shortages, necessity for training and instruction in the area of prevention of infection and specificity of care of a patient infected with SARS-CoV-2 virus, as well as the risk of chronic stress [3]. Awareness of the risk of contracting COVID-19 by medical staff is the source of enhanced psychological tension and stress [4].

Nurses are one of the professional groups greatly engaged in care of a patient with a severe course of COVID-19. Many difficulties in the organization of work, as well as longterm exposure to stressors while performing occupational tasks in hospitals dedicated to coronavirus disease during the period of the COVID-19 pandemic may cause irreversible 
health effects. Therefore, the protection of medical staff working in infectious diseases hospitals during the COVID-19 pandemic is a very important issue.

Objective: The aim of the study is recognition of the conditioning of work of nurses in hospitals dedicated to COVID-19, at the time of pandemic.

\section{Materials and Method}

The study included 100 nursing staff - 78 females (78\%) and 22 males (22\%) employed in Polish hospitals dedicated to care of patients with COVID-19 by virtue of the Minister of Health [5]. The research material was collected during the period from 15 January 2021 - do 12 February 2021. The largest group in the study was aged under 30 (32\%), and similarly those aged $31-40$ (31\%). The respondents aged $41-50$ constituted $21 \%$ of the nursing staff examined. The smallest group of nurses was aged over 60 (16\%). The largest number of the nursing staff lived in urban areas $(78 \%)$, whereas the reminder in rural areas $(22 \%)$.

More than a half of the nurses in the study (57\%) had secondary school education, followed by those with a Master degree (22\%), and a licentiate (21\%).

The study was conducted by the method of a diagnostic survey, using a questionnaire technique, while the research tool was an author-constructed questionnaire designed for the purpose of the presented study. The questionnaires were sent to hospitals dedicated to COVID-19 in various localities in Poland, with a request for obtaining consent from decisionmakers in these facilities. Considering the pandemic, in none of these facilities a consent was expressed to send the documents by post in a paper form. Therefore, the documents were sent by e-mail, and received also in this form. The questionnaire was also posted on a website and the link was provided on the Internet nursing forums.

\section{Results}

A high level of knowledge concerning the COVID-19 pandemic was confirmed by $79 \%$ of the examined nursing staff, followed by a mediocre level - $13 \%$, and a low level $-8 \%$. None of the respondents reported the lack of knowledge pertaining to the COVID-19 pandemic.

Nearly a half of the nurses (47\%) admitted that infectious diseases wards in dedicated hospitals in Poland were prepared to a mediocre degree for admission of an increased number of patients with COVID-19. A high level of preparation was mentioned by $19 \%$ of respondents, whereas $18 \%$ considered that hospital wards were not prepared at all, and $16 \%$ of respondents declared a low level of preparation of infectious wards for admission of an increased number of patients infected with SARS-CoV-2 virus - Tab. 1. 
Table 1. Level of preparation of infectious diseases hospitals for hospitalization of patients with COVID-19.

\begin{tabular}{|l|c|c|}
\hline Level of preparation of hospitals & $\mathbf{n}$ & $\mathbf{\%}$ \\
\hline high & 19 & 19.0 \\
\hline mediocre & 47 & 47.0 \\
\hline low & 16 & 16.0 \\
\hline not prepared & 18 & 18.0 \\
\hline Total & 100 & 100.0 \\
\hline
\end{tabular}

Considering the provision of equipment for care of patients with COVID-19 in infectious diseases hospitals, the examined nurses most often reported that the equipment was sufficient $-59 \%$. Approximately $1 / 3$ of the nurses in the study $(35 \%)$ admitted that the ward where they worked was not equipped according to the needs resulting from the COVID-19 pandemic. A small group of respondents - $6(6 \%)$ were unable to specify whether the amount of equipment was sufficient - Tab. 2 .

Table 2. Provision of infectious diseases wards with adequate amount of equipment for care of patients with COVID-19.

\begin{tabular}{|l|c|c|}
\hline \multicolumn{1}{|c|}{$\begin{array}{c}\text { Provision of hospitals with } \\
\text { equipment }\end{array}$} & n & \% \\
\hline Yes & 6 & 6.0 \\
\hline No & 35 & 35.0 \\
\hline Difficult to specify & 59 & 59.0 \\
\hline Total & 100 & 100.0 \\
\hline
\end{tabular}

While analyzing the research material it was considered important that $19 \%$ of the nurses mentioned that in infectious diseases wards there occurred situations of the lack of equipment in conditions threatening life of patients with COVID-19, including, among other things, the lack of respirators $(5 \%)$, oxygen cylinders (3\%), and defibrillators $(2 \%)$.

Approximately $3 / 4$ of the respondents $(74 \%)$ admitted that the nurse staffing in care of a patient with COVID-19 was insufficient, $10 \%$ of the examined nurses reported that it was rather insufficient, while $8 \%$ of respondents mentioned that the staffing was on a proper level. The remaining group of respondents $(8 \%)$ had no knowledge whether the number of nursing staff at the place where they provided services was sufficient or not.

In opinions of the examined nursing staff the most frequent problems concerning nurse staffing resulted from too small number of nurses on individual duties (78\%), and from prolonged duties $(69 \%)$, followed by illnesses of the staff $(46 \%)$, sick leaves for fear of 
becoming ill $(24 \%)$, rotation to another ward (11\%), and transfer to another hospital $(5 \%)-$ Fig. 1.

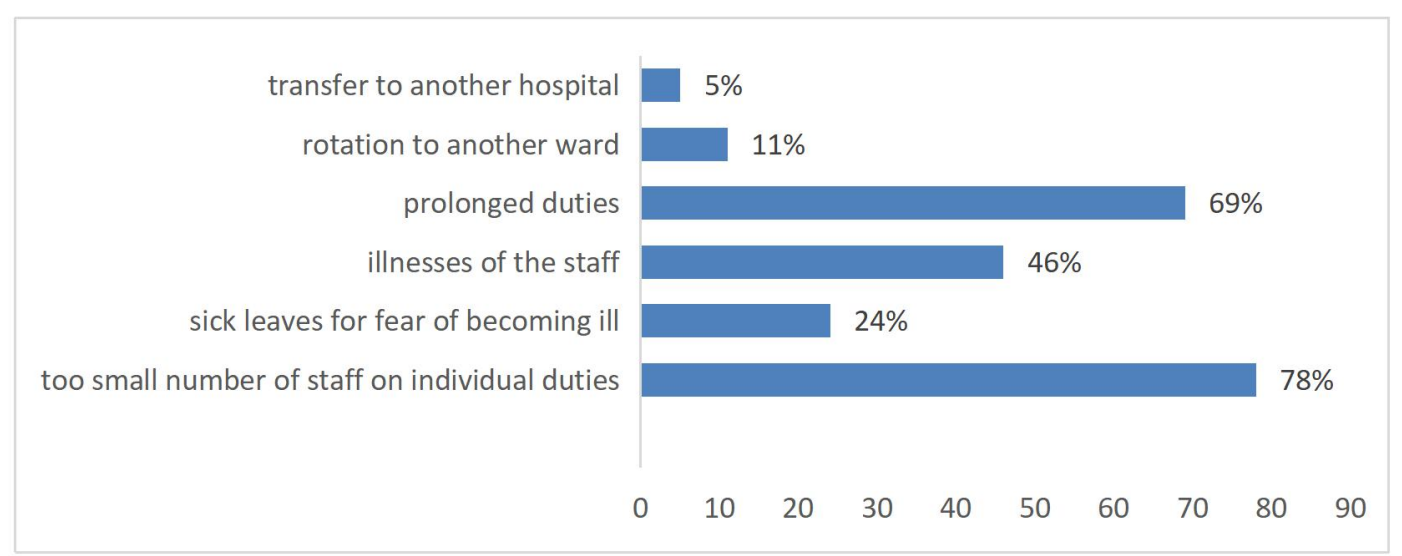

Figure 1. Problems with nurse staffing during care of patients with COVID-19.

In the opinions of the nursing staff in the survey concerning working overtime a large group of nurses $(96 \%)$ worked above the working time limit, while $4 \%$ of respondents worked in accordance with a monthly working time limit.

According to the majority of respondents (78\%) in infectious wards at dedicated hospitals the organization of work was inefficient, $13 \%$ of respondents had difficulty in specifying this, whereas $9 \%$ considered that the work was well organized - Tab. 3 .

Table 3. Assessment of organization of work in infectious ward by nurses.

\begin{tabular}{|l|c|c|}
\hline \multicolumn{1}{|c|}{ Organization of work } & n & \% \\
\hline efficient & 9 & 9.0 \\
\hline inefficient & 78 & 78.0 \\
\hline Difficult to specify & 13 & 13.0 \\
\hline Total & 100 & 100.0 \\
\hline
\end{tabular}

The respondents' answers were analyzed from the aspect of participation in trainings organized at their health units concerning pandemics and management in a crisis situation at a workplace. A large number of respondents (45\%) participated in training; however, many respondents did not participate (41\%), and $14 \%$ of the nurses in the study could not remember - Tab. 4.

Table 4. Participation in trainings concerning pandemic and management in a crisis situation.

\begin{tabular}{|l|c|c|}
\hline \multicolumn{1}{|c|}{ Participation in trainings } & n & \% \\
\hline Yes & 45 & 45.0 \\
\hline No & 41 & 41.0 \\
\hline I do not remember & 14 & 14.0 \\
\hline Total & 100 & 100.0 \\
\hline
\end{tabular}


It was considered important to find out whether during the COVID-19 pandemic additional training courses were organized in hospitals concerning the observance of the principles of safety and work hygiene, in order to reduce the risk of infection among the medical staff. Approximately $3 / 4$ of the examined nurses (74\%) reported that the trainings were organized, $25 \%$ of respondents admitted that the trainings were not organized, while $1 \%$ of them mentioned that they did not remember - Tab. 5 .

Table 5. Participation in additional training courses in the area of OSH during the pandemic.

\begin{tabular}{|l|c|c|}
\hline \multicolumn{1}{|c|}{ Participation in trainings } & n & \% \\
\hline Yes & 74 & 74.0 \\
\hline No & 25 & 25.0 \\
\hline I do not remember & 1 & 1.0 \\
\hline Total & 100 & 100.0 \\
\hline
\end{tabular}

The respondents' replies were analyzed from the aspect of participation in in-hospital trainings concerning the observance of sanitary-hygienic principles, limiting the risk of contracting COVID-19 by the staff. The majority of respondents (75\%) participated in trainings in observance of sanitary-hygienic principles in order to reduce the risk of infection with SARS-CoV-19 virus, $23 \%$ of respondents had no opportunity to participate in this type of trainings, whereas $2 \%$ did not remember the fact of organization of such a training - Tab. 6 .

Table 6. Participation in trainings in the area of sanitary-hygienic principles during the pandemic.

\begin{tabular}{|l|c|c|}
\hline \multicolumn{1}{|c|}{ Participation in trainings } & n & \% \\
\hline Yes & 75 & 75.0 \\
\hline No & 23 & 23.0 \\
\hline I do not remember & 2 & 2.0 \\
\hline Total & 100 & 100.0 \\
\hline
\end{tabular}

The respondents' answers were also analyzed from the aspect of the provision of personal protection means during care of patients ill with COVID-19. The vast majority of respondents $(71 \%)$ reported that in infectious wards there were shortages of personal protection equipment, $16 \%$ of the examined nurses were sufficiently equipped with personal protection equipment, while $13 \%$ of respondents indicated that these means were sometimes insufficient - Tab. 7. 
Table 7. Provision of personal protection means during the pandemic.

\begin{tabular}{|l|c|c|}
\hline $\begin{array}{c}\text { Provision of personal protection } \\
\text { means }\end{array}$ & n & \% \\
\hline sufficient & 16 & 16.0 \\
\hline shortages & 71 & 71.0 \\
\hline sometimes sufficient & 13 & 13.0 \\
\hline Total & 100 & 100.0 \\
\hline
\end{tabular}

In the opinions of the nursing staff in the survey the most frequent shortages of personal protection equipment in infectious wards concerned: protective masks $(54 \%)$, disposable gloves (34\%), face shields (14\%), as well as protective aprons and gowns (8\%).

The respondents' replies were analyzed to discover the occurrence of stress during care of patients with COVID-19. More than a half of the respondents (59\%) experienced a high level of stress, $1 / 3$ of them (34\%) perceived stress on a mediocre level, $7 \%$ - on a minimum level, while there were no respondents who did not perceive stress - Tab. 8 .

Table 8. Level of stress perceived by nurses during care of patients with COVID-19.

\begin{tabular}{|l|c|c|}
\hline \multicolumn{1}{|c|}{ Level of perceived stress } & n & \% \\
\hline high & 59 & 59.0 \\
\hline mediocre & 71 & 71.0 \\
\hline minimum & 13 & 13.0 \\
\hline I do not perceive stress & 0 & 0.0 \\
\hline Total & 100 & 100.0 \\
\hline
\end{tabular}

The majority of nurses $(77 \%)$ considered that chronic stress occurring during care of patients with COVID-19 decreased their effectiveness of work. In the opinions of $14 \%$ of respondents stress had no effect on the outcomes of their work, whereas $10 \%$ of respondents admitted that stress motivated them for more effective work. The main source of stress perceived by the respondents $(93 \%)$ was fear of being infected with SARS-CoV-2 virus.

The respondents' answers were also analyzed concerning the character of negative emotional feelings during care of patients with COVID-19. In the opinions of more than ${ }^{1} / 4$ of respondents (27\%) dominated helplessness, followed by fear for themselves and others $(24 \%)$, stress (13\%), anger (9\%), compassion; sadness (60\% each), and anxiety; occupational burnout (2\% each) - Fig. 2. 


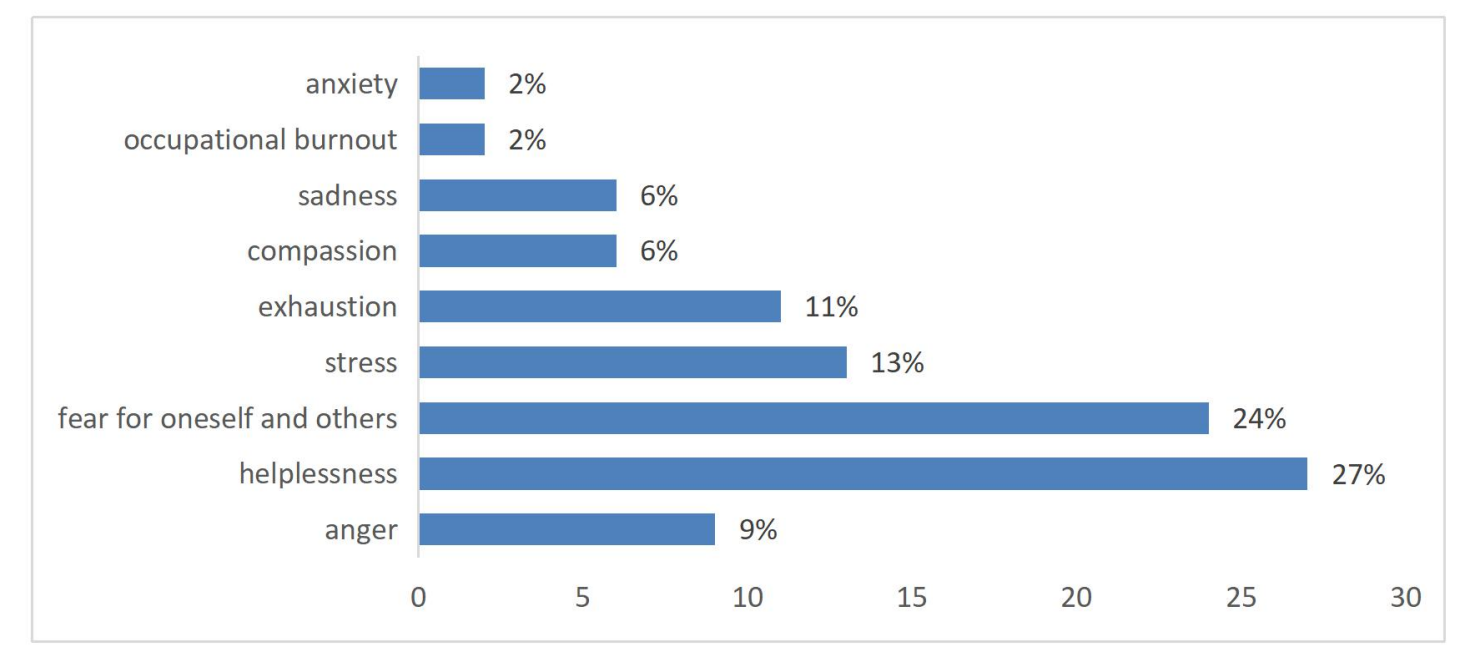

Figure 2. Feelings accompanying nurses during care of patients with COVID-19.

\section{Conclusions}

1. In dedicated hospitals it is necessary to optimize the equipment in the ward indispensable for care of patients with COVID-19, which would improve the working conditions of nurses.

2. It is advisable to adjust the employment of nurses to the demand for nursing care of patients seriously ill with COVID-19, treated in dedicated hospitals.

3. In infectious diseases hospitals, in-hospital training courses should be intensified concerning the OSH and sanitary-hygienic principles in care of patients with COVID-19, because $1 / 4$ of the examined nurses indicated such a need.

4. In dedicated hospitals the nursing staff should be provided with more personal protection equipment, and trainings should be intensified concerning the principles of using the above-mentioned means while taking care of patients with COVID-19.

5. Nurses in dedicated hospitals experienced chronic stress due to the great psychological load during care of patients with COVID-19, which indirectly exerted a negative effect on the effectiveness of their work.

\section{References}

1. Joo JY, Liu MF. Nurses' barriers to caring for patients with COVID-19: a qualitative systematic review. Int Nurs Rev 2021; 68: 202-213.

2. Fernández-Castillo RJ, González-Caro MD, Fernández-García E. Intensive care nurses' experiences during the COVID-19 pandemic: a qualitative study. Nurs Crit Care 2021; 26(5): 397-406. 
3. Gniadek A, Nawara W, Padykuła M, Malinowska-Lipień I. Polska pielęgniarka w czasie pandemii zakażeń SARS-CoV-2 - różne perspektywy wykonywania zawodu. Zdrowie Publiczne i Zarządzanie 2020; 18 (2): 149-154.

4. Kackin O, Ciydem E, Aci OS, et al. Experiences and psychosocial problems of nurses caring for patients diagnosed with COVID-19 in turkey: a qualitative study. Int J Soc Psychiatria 2021; 67: 158-167.

5. Dz. U. 2020 poz. 422. Rozporządzenie Ministra Zdrowia z dnia 12 marca 2020r. w sprawie sposobu i trybu finansowania $\mathrm{z}$ budżetu państwa świadczeń opieki zdrowotnej wykonywanych w związku z przeciwdziałaniem COVID-19. 